\title{
Evapotranspiration is resilient in the face of land cover and climate change in a humid temperate catchment
}

\author{
Stephen K. Hamilton ${ }^{1,2,3}$ (D) | M. Z. Hussain ${ }^{1,2} \mid$ Christopher Lowrie $^{2,4} \mid$ B. Basso ${ }^{1,5}$ | \\ G. P. Robertson ${ }^{1,2,6}$
}

${ }^{1}$ W.K. Kellogg Biological Station, Michigan State University, Hickory Corners, MI 49060, USA

${ }^{2}$ Great Lakes Bioenergy Research Center, Michigan State University, East Lansing, MI 48824, USA

${ }^{3}$ Department of Integrative Biology, Michigan State University, East Lansing, MI 48824, USA

${ }^{4}$ Department of Mathematics, Michigan State University, East Lansing, MI 48824, USA

${ }^{5}$ Department of Earth and Environmental Sciences, Michigan State University, East Lansing, MI 48824, USA

${ }^{6}$ Department of Plant, Soil, and Microbial Sciences, Michigan State University, East Lansing, MI 48824, USA

\section{Correspondence}

Stephen K. Hamilton, W.K. Kellogg Biological Station, Michigan State University, Hickory

Corners, MI 49060, USA.

Email: hamilton@msu.edu

Funding information

US Dept. of Energy, Office of Science, Grant/ Award Numbers: DE-SC0018409 and DEFC02-07ER64494; US National Science Foundation, Division of Environmental Biology, Grant/Award Number: DEB 1027253; Michigan State University AgBioResearch

\begin{abstract}
In temperate humid catchments, evapotranspiration returns more than half of the annual precipitation to the atmosphere, thereby determining the balance available to recharge groundwaters and support stream flow and lake levels. Changes in evapotranspiration rates and, therefore, catchment hydrology could be driven by changes in land use or climate. Here, we examine the catchment water balance over the past 50 years for a catchment in southwest Michigan covered by cropland, grassland, forest, and wetlands. Over the study period, about $27 \%$ of the catchment has been abandoned from row-crop agriculture to perennial vegetation and about $20 \%$ of the catchment has reverted to deciduous forest, and the climate has warmed by $1.14^{\circ} \mathrm{C}$. Despite these changes in land use, the precipitation and stream discharge, and by inference catchment-scale evapotranspiration, have been stable over the study period. The remarkably stable rates of evapotranspirative water loss from the catchment across a period of significant land cover change suggest that rainfed annual crops and perennial vegetation do not differ greatly in evapotranspiration rates, and this is supported by measurements of evapotranspiration from various vegetation types based on soil water monitoring in the same catchment. Compensating changes in the other meteorological drivers of evaporative water demand besides air temperature-wind speed, atmospheric humidity, and net radiation-are also possible but cannot be evaluated due to insufficient local data across the 50-year period. Regardless of the explanation, this study shows that the water balance of this landscape has been resilient in the face of both land cover and climate change over the past 50 years.
\end{abstract}

\section{KEYWORDS}

climate change, crops, evaporation, evapotranspiration, forest, land use

\section{1 | INTRODUCTION}

In temperate humid catchments, evapotranspiration (ET) returns more than half of the annual precipitation to the atmosphere (Hanson, 1991; Williams et al., 2012; Zhang et al., 2016), mainly during the growing season by plant transpiration (Donohue, Roderick, \& McVicar, 2007). The balance between precipitation and ET recharges groundwaters and supports stream flow and lake levels. Paired catchment studies often have shown that changes in the nature of the vegetation cover,

A pre-peer reviewed version of this article has been placed at https://doi.org/ 10.1101/075598 especially deforestation or afforestation, alter ecosystem ET rates and thereby change stream flows (Bosch \& Hewlett, 1982; Brown, Westem, McMahon, \& Zhang, 2013; Brown, Zhang, McMahon, Westem, \& Vertessy, 2005; Hornbeck, Adams, Corbett, Verry, \& Lynch, 1993; Price, 2011 and Zhang, Dawes, \& Walker, 2001). However, these studies are often conducted in small experimental catchments and generally compare stream water yields between two kinds of perennial vegetation (woody and herbaceous).

There have been fewer catchment-scale comparisons of water yield from annual vegetation such as maize (Zea mays, known as corn in the United States) and soybean (Glycine max) versus perennial vegetation such as forest or grasslands (Price, 2011), yet land cover change from

This is an open access article under the terms of the Creative Commons Attribution License, which permits use, distribution and reproduction in any medium, provided the original work is properly cited.

(c) 2018 The Authors. Hydrological Processes published by John Wiley \& Sons Ltd. 
perennial vegetation to cropland and vice versa has occurred throughout the world as a result of agricultural expansion and contraction. In eastern North America, the original forests and grasslands were largely converted to agricultural lands by European settlers, but since the mid1900s, a substantial fraction of the converted land has reverted back to successional fields and forests as the more marginal agricultural lands were abandoned due to low profitability, poor suitability to mechanized cultivation, and concerns about soil erosion and degradation (Houghton \& Hackler, 2000; Ramankutty, Heller, \& Rhemtulla, 2010).

Land cover in agricultural regions is expected to continue to change in the future. As grain crops have become more profitable over the past decade due to global demand for food and U.S. policies that support ethanol production from maize, more land in grasslands (including Conservation Reserve Program land) is being converted to grow maize and soybean (Lark, Salmon, \& Gibbs, 2015). Meanwhile, successional ecosystems are becoming mature forests in many locations (Pugh, 2015). Climate change and invasive plant species will increasingly drive changes in the nature and phenology of vegetation communities (Parmesan \& Hanley, 2015; Simberloff, 2000). Further changes to the nature of vegetation in agricultural landscapes may occur if cellulosic biofuel crops are increasingly grown in the future (Gelfand et al., 2013).

Recently, we reported ET measurements in candidate cellulosic cropping systems at a location in southwest Michigan, USA using two distinct approaches: (a) by monitoring soil water content with time domain reflectometry in annual crops (maize) as well as perennial grasslands and hybrid poplar stands (Hamilton, Hussain, Bhardwaj, Basso, \& Robertson, 2015); and (b) by monitoring energy and water vapour fluxes using eddy covariance in maize, switchgrass, and prairie at a nearby site (Abraha et al., 2015). Results suggest strikingly similar growing-season ET among these diverse plant systems, raising the question of whether land cover changes would significantly affect ET in the Midwest United States, as suggested in some modelling studies (e.g., Le, Kumar, \& Drewry, 2011; VanLoocke, Twine, Zeri, \& Bernacchi, 2012; Zhuang, Qin, \& Chen, 2013).

The objective of this study is to examine trends in ET over 50 years in a particularly well-characterized, temperate humid catchment that has experienced significant land cover change, but without the complications of urbanization, dams, and stormwater management changes that are typical of larger catchments. We infer ET from the balance between precipitation and discharge, and the results are compared with our independent measurements of ET made on annual and perennial vegetation in the same catchment.

\section{2 | METHODS}

\section{1 | Study site}

Augusta Creek is a 3rd-order stream in southwest Michigan (Kalamazoo and Barry counties) that drains a predominantly rural landscape $\left(95 \mathrm{~km}^{2}\right)$ composed of a mosaic of forest, fallow fields, annual crops, wetlands, lakes, light residential development, and golf courses (Figure 1). There are no impervious surfaces or storm drainage systems that drain into the stream above the discharge measurement point, and urban land use covers just $2.4 \%$ of the catchment (land cover proportions over the 50 -year period are presented later). The stream is

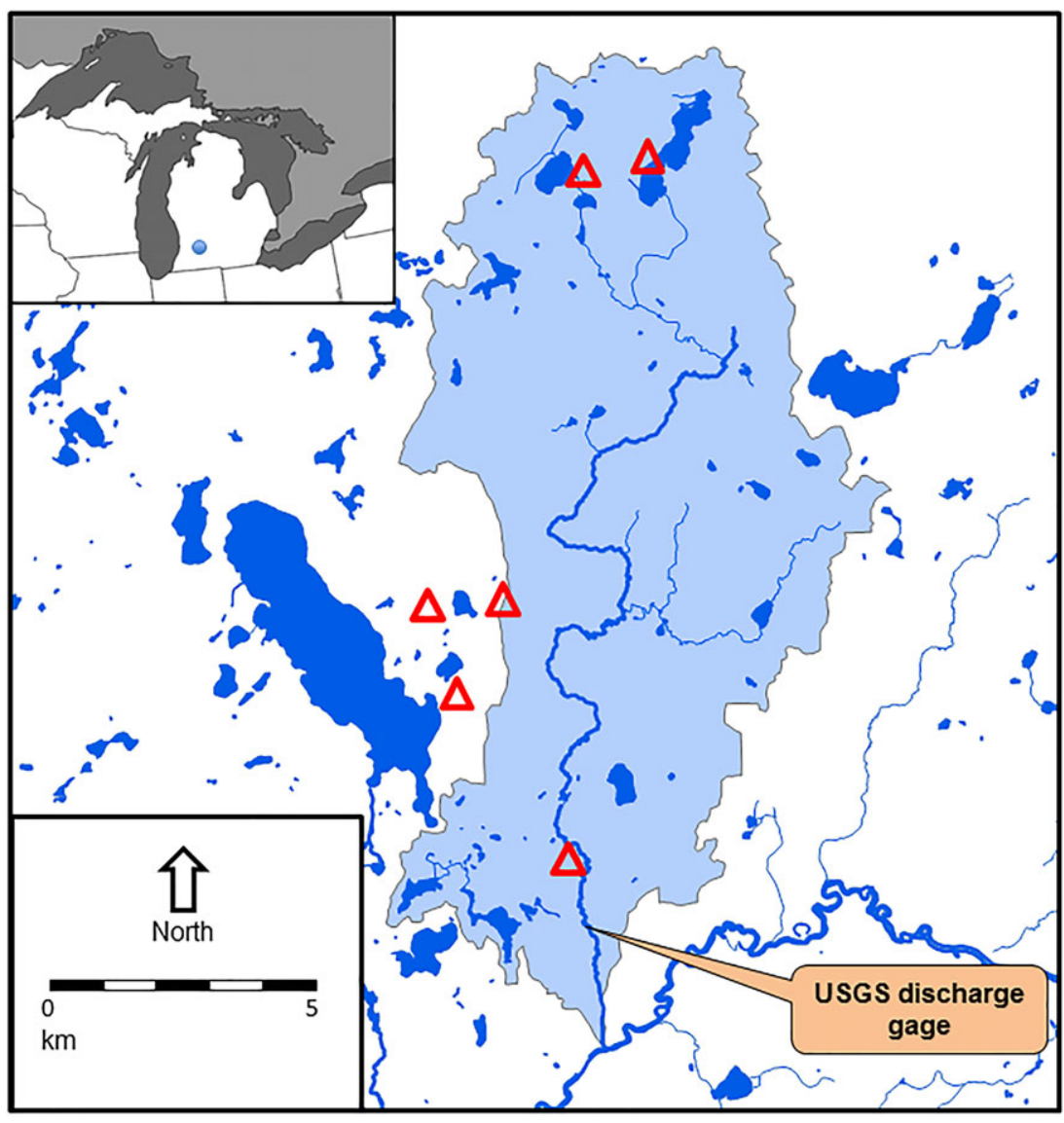

FIGURE 1 Location of Augusta Creek in Michigan (inset) with catchment boundaries shaded in light blue and lakes and stream channels shaded in dark blue. Precipitation measurement sites are shown by triangles. USGS = United States Geological Survey 
groundwater-fed, gaining water along most of its length. Its tributaries emanate from wetlands or small lakes, and prairie fen wetlands line much of the stream channels.

The stream runs through deep glacial deposits that lie well above the bedrock. The most common soils in upland areas are well-drained Typic Hapludalfs developed on postglacial terrain (Thoen, 1990), and there is little to no overland flow from upland areas to the stream due to the high permeability of these coarse-textured soils (Rheaume, 1990). Irrigation of crops was rare in the area until very recently; some expansion has taken place since 2005 , supplied by groundwater wells.

Augusta Creek is in the vicinity of the W.K. Kellogg Biological Station (KBS), where we conduct agricultural experiments under the aegis of the Great Lakes Bioenergy Research Center and KBS Long Term Ecological Research site (www.Iter.kbs.msu.edu; $42.3956^{\circ} \mathrm{N}$, $85.3749^{\circ} \mathrm{W}$, and $288 \mathrm{~m}$ asl). Mean annual air temperature is $10.1^{\circ} \mathrm{C}$ and annual precipitation is $1,005 \mathrm{~mm}, 511 \mathrm{~mm}$ of which falls as rain during the May-September growing season (1981-2010; NCDC (National Climate Data Center), 2013). In this region, ET is normally water-limited during the warmer part of the year (i.e., during at least part of the growing season), and energy-limited during the cooler months (McVicar, Roderick, Donohue, \& Van Niel, 2012).

\section{2 | Land cover changes}

Land cover for 1960 was estimated from georectified and mosaicked aerial photographs in a geographic information system (ArcGIS; details in Supplementary Information). The catchment boundaries above the discharge measurement point (U.S. Geological Survey; Hydrologic Unit Codes 04050003040060 plus 04050003040070 ) and wetlands and lakes (National Wetlands Inventory: http://www.fws.gov/wetlands/) were overlain on the aerial photo mosaic, and land cover was examined in the upland portions of the catchment. Based on the National Wetlands Inventory, wetlands and lakes contiguous with the stream system amount to $15.9 \mathrm{~km}^{2}$, which is $16.6 \%$ of the catchment. Isolated wetlands and small lakes also occur throughout the upland catchment, covering $5.2 \%$ of its area. Wetland areas were assumed to be constant over the study period; there has been no wetland drainage or creation in the catchment since 1960, and within the area mapped, wetland boundaries generally include intermittently wet soils with high water tables as well as areas with surface water.

Land cover for 2014 was estimated from the Cropland Data Layer (http://nassgeodata.gmu.edu/CropScape/). For this purpose, we combined all field crops (primarily maize, soybean, and small grains) into the annual crop category, and all forests (deciduous and coniferous) into the forest category. Conifers are not native to the upland landscape here but have been planted throughout the catchment; their total area as of 2014 amounts to $~ 3 \%$ of the total forest area and $1 \%$ of the upland catchment. The grassland and pasture category includes hay as well as fallow fields (no native grassland remains). The width of rural roads was exaggerated threefold-fivefold in the Cropland Data Layer, presumably due to automated classification of mixed pixels, so vegetated edges of roadways were manually reclassified as grasslands. Land cover for an intermediate date (1978), based on aerial photo interpretation, was available from the Michigan Resource Inventory System (MIRIS; http://www.ciesin.org/IC/mdnr/ mrip.html); this data set was comparable for forest but combines annual crops with some kinds of pasture and was therefore not compared for those categories.

\subsection{Discharge and climate records}

The U.S. Geological Survey has monitored the discharge of Augusta Creek below the lowermost tributary inflow since 1964 (station 04105700; details in Supplementary Information). The long-term mean discharge at this point, which drains $95.3 \mathrm{~km}^{2}$, is $1.28 \mathrm{~m}^{3} \mathrm{~s}^{-1}$. Daily discharge measurements for October 1964 through September 2014 were partitioned into baseflow and stormflow using the Web-based Hydrograph Analysis Tool described by Lim et al. (2005). Mean annual baseflow and stormflow discharges were calculated on a standard United States water-year basis beginning on October 1 of each year, representing the transition between warm and cool seasons, and water years are labelled by the starting year (i.e., water year 1964 is October 1, 1964-September 30, 1965).

Climate data were drawn from several sources and compiled on a water-year basis. Precipitation observations are from at least three stations (except 1992 which has two) distributed across the catchment from north to south (Figure 1; details in Supplementary Information). Air temperature, saturated vapour pressure, and drought index data were obtained from the Midwest Regional Climate Center (http:// mrcc.isws.illinois.edu/).

\subsection{Estimation of ET from water balances}

ET has often been estimated from catchment water balances (e.g., Zhang et al., 2016). For Augusta Creek, the water balance for the upland portion of the catchment was determined as the difference between annual totals of precipitation falling on the uplands (i.e., the catchment excluding wetlands and lakes contiguous with the stream channels) and the annual stream baseflow discharge. Isolated lakes and wetlands were included in the upland catchment area. The difference between precipitation inputs on the uplands and stream baseflow outputs is therefore considered to represent the ET of the upland catchment.

This approach to ET estimation assumes that stormflow represents direct capture of precipitation from the wetlands and lakes contiguous with the stream system, whereas baseflow represents infiltration and percolation of precipitation falling on the upland catchment. The validity of this assumption is supported by the water balance calculations (see Section 3) as well as the high permeability of the soils in the uplands (Rheaume, 1990). Other assumptions that are reasonable in this case include no interbasin transfers of water, which is true in this catchment, and no significant trend in water storage in the aquifer or surface water bodies over the study period. Although there are no continuous water table measurements spanning this study period, water levels of local lakes that are connected to the groundwater have shown no unidirectional trend since the late 1960s (see Figure S1 for an example of water level data for a lake in the Augusta Creek catchment). Additional evidence for no interannual trend in groundwater levels is provided by a compilation of static water level measurements that are made when residential water supply 
wells are constructed, which shows no trend over the study period (Figure S2).

\section{5 | ET estimation from soil water content measurements}

Since 2009, soil water profiles throughout the root zone and below were monitored hourly using permanently installed, horizontally inserted time domain reflectometry probes at depths of $20,35,50$, 65,90 , and $125 \mathrm{~cm}$ as well as a vertically inserted probe at $0-10 \mathrm{~cm}$ depth. Our methods for estimating ET from soil water profiles are described by Hamilton et al. (2015), who presented data on six biofuel cropping systems harvested each fall. The time domain reflectometry measurements provide an estimate of ET when daily drawdowns in soil water can be measured and the soil water content is below its drained upper limit, which is typical of most of the growing season. The sum of the daily drawdowns in soil water content over the entire profile $(0-150 \mathrm{~cm})$ across the growing season provides an estimate of ET; on days when new infiltration of rain water prevented a measurable soil water drawdown, we estimated ET using a crop growth model (Basso \& Ritchie, 2012). More details are provided in the Supplementary Information.

Here, we present the mean ET rates for three of those systems that resemble vegetation found on the broader landscape: (a) continuous no-till maize; (b) a restored native prairie planted with 18 species of forbs and grasses; and (c) a hybrid poplar plantation (Populus nigra $\times$ Populus maximowiczii 'NM6'). In addition, we present comparable water use measurements for three other systems in the same vicinity: (a) a fallow field abandoned from row-crop agriculture in 2008 and harvested each fall; (b) a mature deciduous forest ( $>50$ years old) dominated by sugar maple (Acer saccharum), red oak (Quercus rubra), and hickory (Carya spp.) trees; and (c) an early successional forest (ca. 25 years old) dominated by shrubs including autumn olive (Elaeagnus umbellata) and honeysuckle (Lonicera sp.) as well as a few medium-sized sugar maple and black cherry (Prunus serotina) trees.

All data reported here are openly available at http://datadryad. org/resource/doi:10.5061/dryad.6fm52.

\section{3 | RESULTS}

\subsection{Land use and climate changes}

Maize has been the dominant agricultural crop over the 50-year study period with the balance of harvested crops shifting increasingly to soybean since the 1970 s, as in the greater Midwest U.S. region (Gage, Doll, \& Safir, 2015). Data on Kalamazoo County from the annual Census of Agriculture (U.S. Department of Agriculture: http://www. agcensus.usda.gov/) indicate that in 1964 maize accounted for $69 \%$ of harvested cropland, soybean for $5.7 \%$, and the balance was mostly oats with some barley and wheat. By 1987, maize was 58\% and soybean $28 \%$ of harvested cropland, and by 2007 , these two crops accounted for $64 \%$ and $32 \%$ of the harvested cropland.

Land cover in the upland catchment changed significantly between 1960 and 2014 (Figure 2). The proportion of the upland

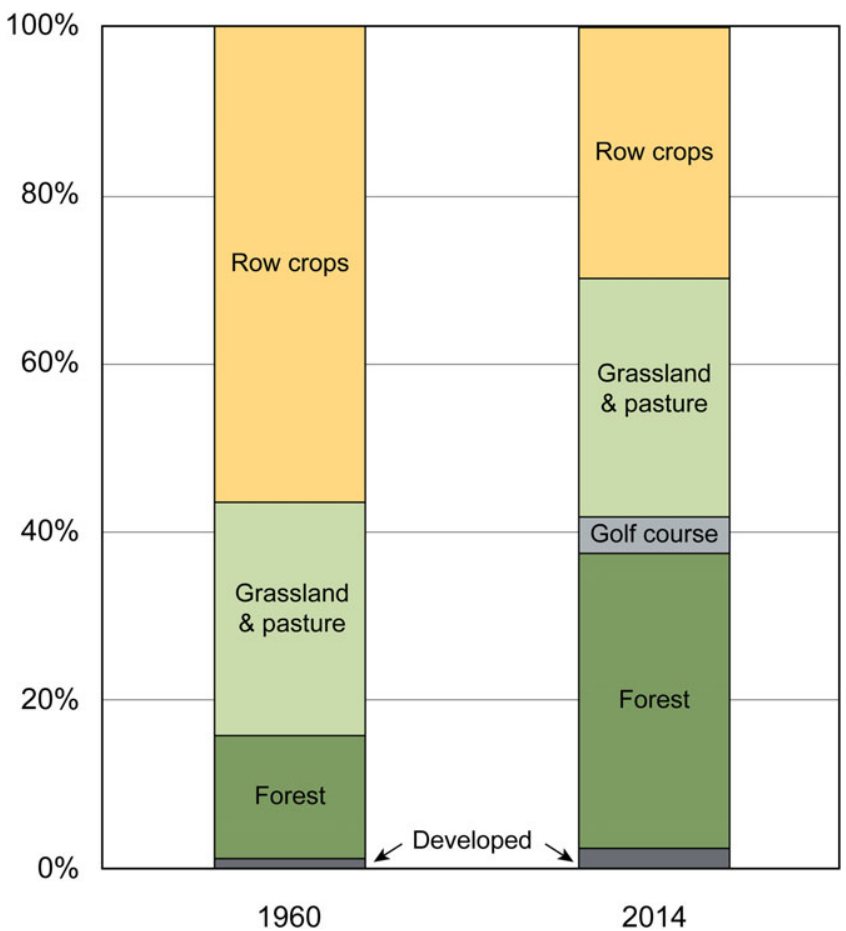

FIGURE 2 Land cover change in the Augusta Creek catchment. Estimates are based on analysis of aerial photos (1960) or satellite imagery (2014 Cropland Data Layer: http://nassgeodata.gmu.edu/ CropScape/)

catchment in annual crops decreased from $57 \%$ to $30 \%$, whereas forest increased from $15 \%$ to $35 \%$. The proportion of grassland remained similar, although only $20 \%$ of the 1960 upland grassland was still grassland in 2014; most of the 1960 grassland became forest (43\%) or cropland (22\%), whereas some newly abandoned cropland became grassland. The 1978 MIRIS land cover data (not shown; see Section 2) indicate that $94 \%$ of the forest present in 2014 existed by 1978, and therefore most reforestation began between 1960 and 1978. Urban and residential development represents a small fraction of the catchment $(<2.4 \%)$, not including golf courses created during the study period that covered $4.5 \%$ of the upland catchment by 2014 (the golf courses occasionally irrigate during dry summers but are not significant water users at the catchment scale). Similar changes in land cover occurred in adjacent catchments.

Annual precipitation for the Augusta Creek catchment over the 50 years averaged $948 \pm 118 \mathrm{~mm} \mathrm{year}^{-1}$ (mean \pm s.d.) with no linear temporal trend ( $p=.93$; Figure 3a). No linear trend exists in mean annual values for either the Palmer Drought Severity Index or the Palmer Hydrological Drought Index $(p=.34$ and 0.67, respectively; Figure S3).

One or more of the four meteorological variables that control atmospheric evaporative demand-wind speed, atmospheric humidity, net radiation, and air temperature-could have changed over the 50 years, as global- and continental-scale analyses have indicated significant changes in these variables in recent decades (McVicar, Roderick, Donohue, Li, et al., 2012; Wild, 2009; Willett, Jones, Gillett, \& Thorne, 2008). The effects of changes in these variables on 
FIGURE 3 Precipitation, stream discharge, and evapotranspiration (ET). Panels show annual (October-September) values of (a) precipitation measured at 3-6 stations (mean = blue line); (b) stream discharge partitioned into baseflow and stormflow; (c) evapotranspiration (ET) estimated as the difference between precipitation and baseflow discharge; and (d) ET as a percentage of annual precipitation. Horizontal lines show the means
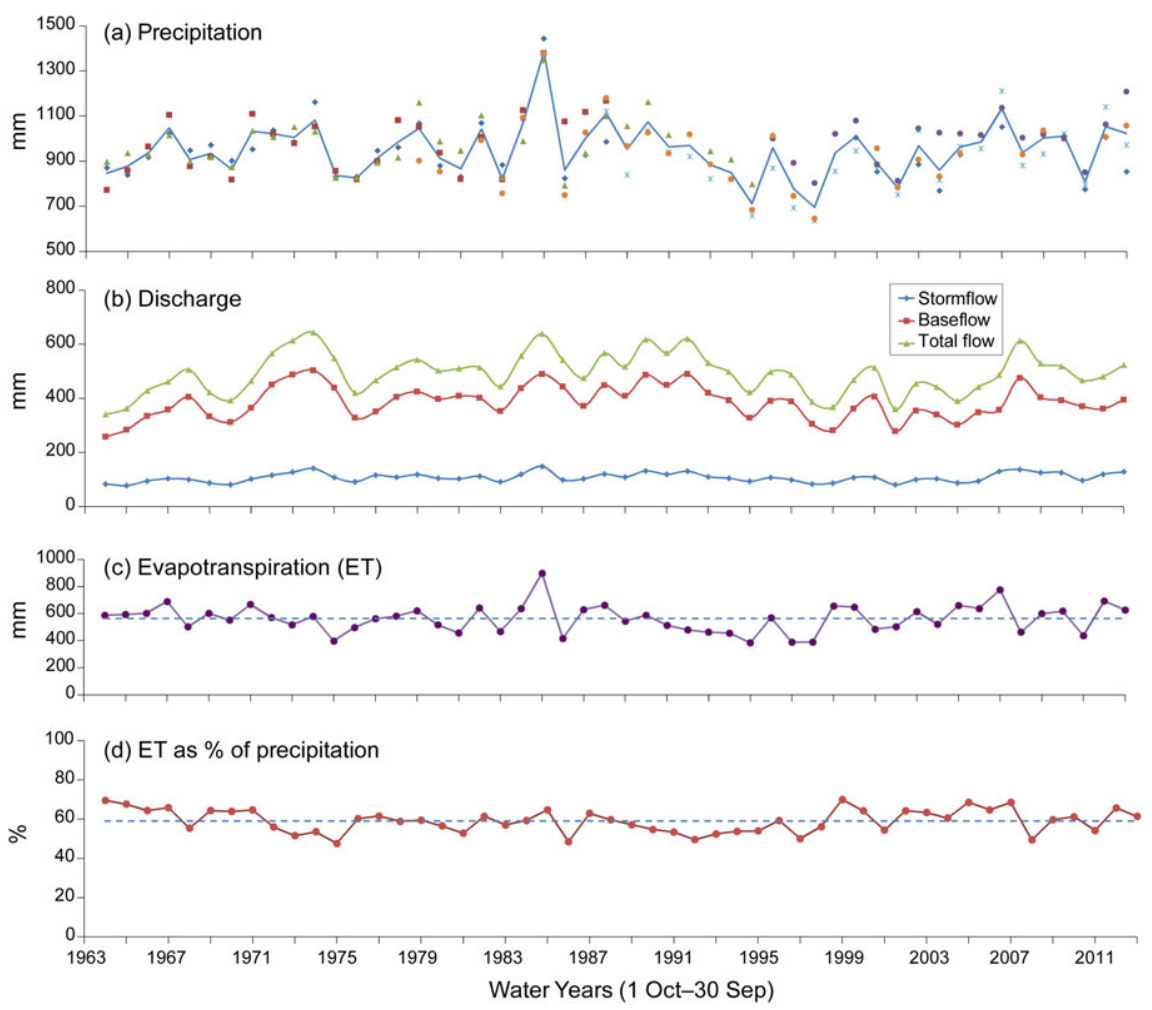

atmospheric evaporative demand could be to enhance or counteract each other, and the resultant effect on ET is particularly important where evaporation is limited by energy rather than water (e.g., decreasing wind speeds tend to counteract the effect of increasing temperatures: McVicar, Roderick, Donohue, \& Van Niel, 2012, McVicar, Roderick, Donohue, Li, et al., 2012). The region has experienced a $1.14{ }^{\circ} \mathrm{C}$ increase in mean annual air temperature (50-year mean $=8.95{ }^{\circ} \mathrm{C}$ ) which in turn equates to a 0.90 millibar $(\mathrm{mb})$ increase in saturated vapour pressure $(50$-year mean $=13.5 \mathrm{mb})$ over

(a) Air temperature

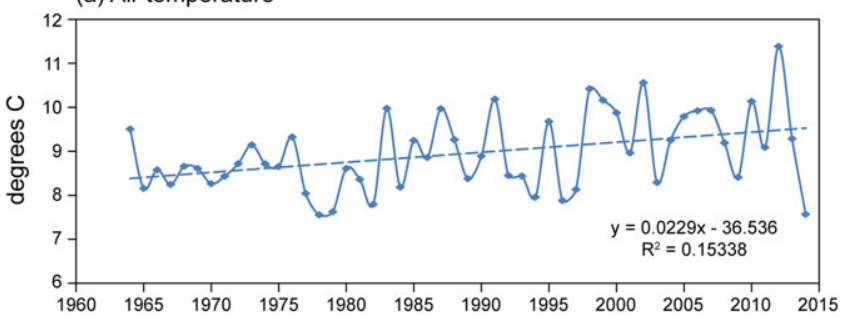

(b) Saturated vapor pressure

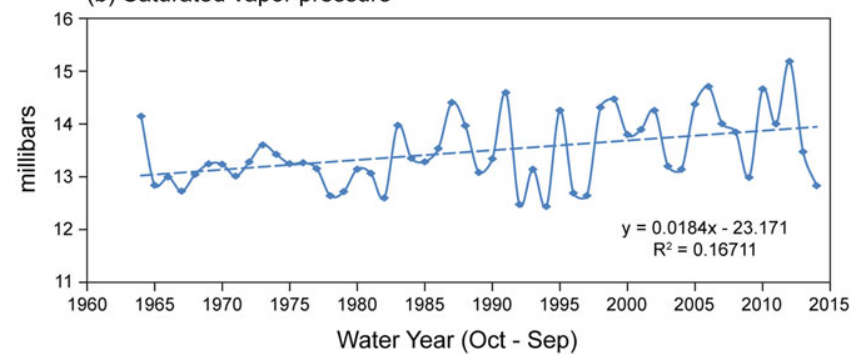

FIGURE 4 Air temperature (a) and saturated vapour pressure (b) for the Augusta Creek catchment, derived from the Midwest Regional Climate Center database (http://mrcc.isws.illinois.edu/). The positive change is significant $(p=.005)$ and amounts to $1.14{ }^{\circ} \mathrm{C}$ over the 50 years the 50-year period (Figure 4). Consistent data across the study period for wind speed, atmospheric humidity, and net radiation are not available for this locale.

\section{2 | Catchment hydrology}

Stream discharge partitioned into stormflow and baseflow shows how groundwater dominates the total flow of Augusta Creek; baseflow averaged $78 \%$ of the total discharge (Figure $3 \mathrm{~b}$ ). There is no linear trend in total $(p=.14)$, stormflow $(p=.91)$, or baseflow $(p=.83$ ) discharge over the 50 years. In this catchment, stormflow likely reflects mainly precipitation falling on lakes and wetlands that are contiguous with the stream channels because upland soils are highly permeable and there are few impervious surfaces and little overland runoff from uplands to the streams. This is supported by the comparison of annual stormflow volumes to the annual precipitation falling on contiguous lakes and wetlands: on average, stormflow amounts to 57\% (range, 44-73\%) of the precipitation with no linear trend over the 50 years ( $p=.09$, data not shown). The balance, which equates to a mean of $408 \mathrm{~mm}$ year $^{-1}$, could largely be explained by evapotranspirative losses from the lakes and wetlands. If stormflow originating as overland flow from the uplands were important, the total stormflow volume would exceed the precipitation on lakes and wetlands.

Our annual water balances for Augusta Creek resemble earlier estimates calculated by Rheaume (1990) over three representative years $(1971,1977$, and 1985), which indicated that $62 \%, 65 \%$, and $59 \%$, respectively, of the annual precipitation was returned to the atmosphere as ET, mainly during the growing season (May-September), although those estimates included ET from contiguous lakes and wetlands as well as uplands. That study also employed hydrograph separation to estimate that about $75 \%$ of 
the annual stream flow in those years was supported by groundwater discharge; our estimate of mean baseflow contribution over the 50 -year period is $78 \%$.

Our estimate of ET, based on the difference between precipitation on the upland catchment and baseflow discharge out of the catchment, averaged $563 \pm 103 \mathrm{~mm}$ year $^{-1}$ (mean \pm s.d.; Figure 3c), with no linear trend $(p=.98)$. Expressed as a percentage of annual precipitation, ET averaged $59 \pm 6 \%$ (mean \pm s.d.; Figure $3 \mathrm{~d}$ ), also with no trend over the 50 years ( $p=$.88). Therefore, these data show that ET from upland areas of the Augusta Creek catchment has remained remarkably stable over the past 50 years in spite of large changes in land cover towards less area in annual crops and more in deciduous forest.

\section{3 | ET rates from representative vegetation types}

We estimated ET in annual crops and perennial vegetation over the 2009-2014 period from high-resolution changes in soil water profiles (Figure 5). Except for 2012, which was a drought year, mean growing season ET rates (mean \pm s.d.) were $495 \pm 48 \mathrm{~mm}_{\text {year }}{ }^{-1}$ for maize, $524 \pm 79$ for grasslands (fallow and prairie), and $532 \pm 47$ for woody vegetation (deciduous forest, shrubland, and poplar). These rates are statistically indistinguishable among vegetation types $(p>.05)$, further supporting the hypothesis that ET rates are similar among annual crops, perennial grasslands, and forests in the Augusta Creek catchment. These ET observations span years of varying warmth (Figure 4) but show no relationship with mean growing-season temperature.

While soil water-based ET rates, excluding the 2012 drought year, are lower than the water balance-based ET rates of $600 \pm 59 \mathrm{~mm} \mathrm{year}^{-1}$ (mean \pm s.d.) in those years (2009, 2010, 2011, 2013, and 2014 in Figure 3c), the soil water-based ET estimates reflect only the growing seasons. Year-round eddy covariance measurements of water fluxes in maize and grasslands at KBS indicate that about $30 \%$ of ET occurs outside the May-September growing season (Abraha et al., 2015). Adding 30\% to the soil water-based ET rates brings rates for maize, grasslands, and woody vegetation to 643, 681, and $692 \mathrm{~mm} \mathrm{year}{ }^{-1}$, respectively, all higher but within $15 \%$ of the catchment-based ET measurements over those years.

\section{4 | DISCUSSION}

The 50-year record of precipitation, stream discharge, and by inference ET shows no long-term trends, and the catchment water balance has thus displayed resilience in spite of changing land cover (Figure 2) and warming temperatures (Figure 4). Annual ET from the upland portion of the catchment appears to have been stable. This stability in ET suggests that rainfed annual crops and perennial vegetation do not differ greatly in ET rates, and this is supported by measurements of ET from various vegetation types based on soil water monitoring in the same catchment (Figure 5).

\section{1 | Possible explanations for the stability of ET}

There are several possible explanations for the long-term stability of catchment ET that we believe are unlikely. One is that there may not have been sufficient time for hydrologic responses to be detected. While the mean transit time for groundwater movement in this kind of catchment is likely greater than a decade (e.g., Saad, 2008), groundwater discharge rates from an unconfined and connected aquifer system would respond to changing recharge at far faster time scales (McDonnell \& Beven, 2014). Succession from grassland to forest can be protracted, but the MIRIS forest cover data indicate that most of the reforestation occurred in the first 14 years of the study period (i.e., 1964-1978). Many long-term paired catchment studies have shown that water yield after regrowth of harvested forest tends to approach a stable rate within about 10-25 years (Brown et al., 2013; Hornbeck et al., 1993).

Another possibility is that the degree of land cover change over the study period ( $27 \%$ of the upland catchment abandoned from annual crops and $20 \%$ of it becoming reforested; Figure 2) may not be sufficiently large to signal a change in water yield, even if annual crops and perennial vegetation had large differences in ET rates. Again, this is unlikely because long-term paired catchment studies have shown significant change with as little as $20 \%$ of the catchment either deforested or afforested (Brown et al., 2005).

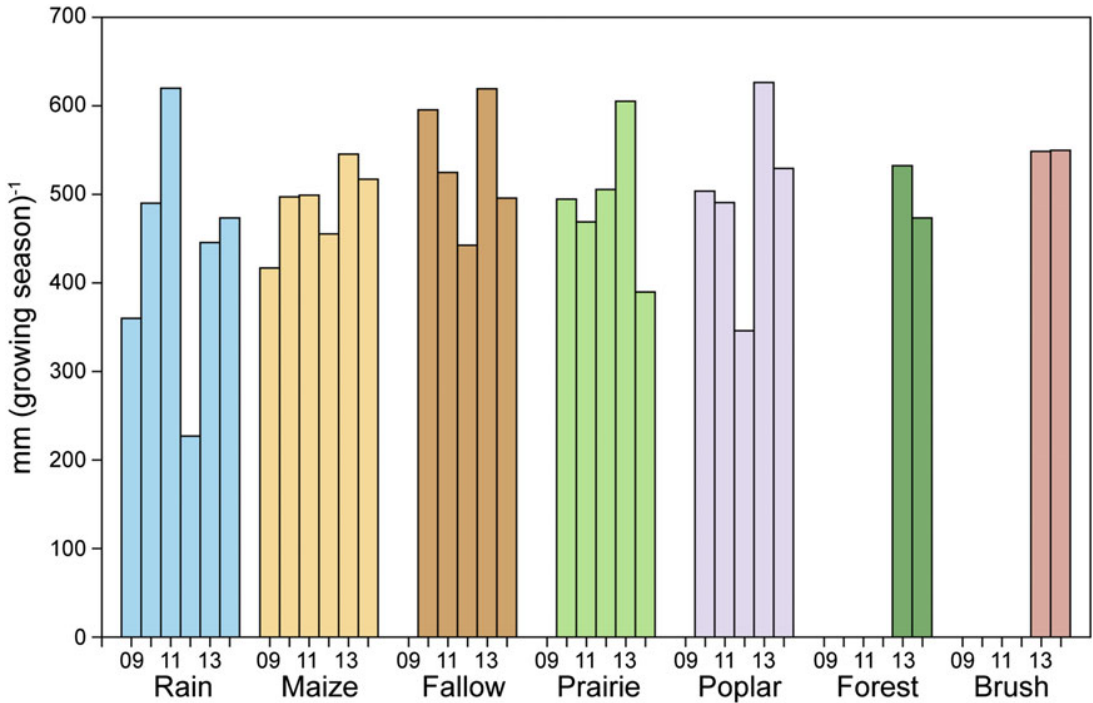

FIGURE 5 Rainfall (blue bars on far left) and evapotranspiration (remaining bars) over the growing season (2009-2014) from annual maize and herbaceous and perennial vegetation, estimated from continuous observations of plant water uptake in soil profiles. Number on $x$-axis show every other year (i.e., 2009, 2011, and 2013) 
Also possible is that there are offsetting effects exerted by different land covers in the vicinity (Albertson, Katul, \& Wiberg, 2001; Van Dijk, Peña-Arancibia, \& Bruijnzeel, 2012), but this does not seem likely because adjacent catchments have similar mosaics of land cover, and the entire region has experienced similar changes in vegetation over this time period. Compensating land use changes that result in no net change in ET are also a possibility, such as the changes in crops grown as noted above. However, the ET rate of oats that were commonly grown in the 1960s and 1970s is unlikely to differ much from the maize that replaced them (Allen, Pereira, Raes, \& Smith, 1998).

Over the past 50 years, the mean annual air temperature has increased by about $1.14{ }^{\circ} \mathrm{C}$ (Figure 4), and the frost-free season has become longer by about 9 days (Kunkle, 2015). ET could increase with warming if available water were not limiting, other meteorological changes did not offset the temperature effect (McVicar, Roderick, Donohue, Li, et al., 2012), and the vegetation could remain active over the longer growing season. However, during the growing season when most $(\sim 70 \%)$ of the ET occurs, available soil water typically becomes limiting to ET (Hamilton et al., 2015). Also, most annual crops and many grasses would senesce before the end of the potential growing season because their development is regulated by degree-days (Parmesan \& Hanley, 2015).

Extrapolation of observations from small catchments that are entirely covered by one kind of vegetation to complex mixtures of vegetation may not be as straightforward as it would seem. Models of ET and discharge from catchments with mixed land covers have often proven challenging to validate, and a variety of possible reasons have been considered (Van Dijk et al., 2012). Methodological issues identified by those authors include uncertainties in land cover, precipitation, and discharge data; in the case of the Augusta Creek catchment, however, the precipitation and land cover data are likely to be quite accurate. It is also possible that other catchment climate characteristics that we have not considered are more influential to ET than land cover (e.g., Wilcox \& Huang, 2010). Physical explanations noted by Van Dijk et al. (2012) for poor model performance include recirculation of intercepted rainfall, which tends to be more important in forests, and lateral water redistribution between vegetation types; identifying the potential importance of these physical explanations in the Augusta Creek catchment is beyond the scope of this study.

We cannot rule out the possibility that changes in the meteorological drivers of atmospheric water demand (i.e., temperature, net radiation, wind speed, and atmospheric humidity; McVicar, Roderick, Donohue, \& Van Niel, 2012, McVicar, Roderick, Donohue, Li, et al., 2012) could have offset the effects of land cover changes on ET. The steadily increasing partial pressure of atmospheric carbon dioxide could also have reduced plant transpiration rates, although its effect on ET is most pronounced in warm, highly water-limited (i.e., arid and subarid) regions (Donohue, Roderick, McVicar, \& Farquhar, 2013; Trancoso, Larsen, McVicar, Phinn, \& McAlpine, 2017; Yang, Donohue, McVicar, Roderick, \& Beck, 2016). In any case, the offset of land cover effects on ET by these atmospheric changes would be a regional phenomenon contributing to the resilience of catchment ET and discharge.

\section{5 | CONCLUSION}

Evapotranspirative water loss in the upland portion of the Augusta Creek catchment has been remarkably resilient across a 50 -year period of decreasing cropland, increasing perennial vegetation cover, and warming temperatures, leaving a relatively consistent proportion of precipitation for groundwater recharge and streamflow. Our ET estimates based on catchment water balances compare well with direct measurements in the same catchment since 2009 based on soil water monitoring by time-domain reflectometry for grasslands, annual crops, and perennial bioenergy crops and forest. These observations suggest that water use by rainfed annual crops and perennial vegetation is similar in this setting, and that in humid catchments with soil permeability little affected by land cover, catchment water balances are not likely to be very sensitive to near-term future changes in land cover and climate as long as the land is vegetated, and crops are not irrigated. One such land cover change could be an increase in the cultivation of perennial herbaceous crops for biofuel production, which, based on our findings, does not seem likely to alter catchment water balances in this kind of setting.

\section{ACKNOWLEDGMENTS}

We thank A. K. Bhardwaj, S. Bohm, K. Kahmark, and S.-G. Li for instrumentation and data assistance, local citizens W. Shafer, T. Smith, and W. Knollenberg for precipitation data supplemental to that from our research and National Weather Service stations, and the numerous people at Michigan State University and the U.S. Geological Survey who helped maintain the precipitation and stream discharge records since 1964. T. McVicar, J.J. McDonnell and T. Dunne read earlier versions and provided helpful advice on data interpretation. Financial support for this work was provided by the U.S. Department of Energy through the Great Lakes Bioenergy Research Center (DOE BER Office of Science DE-FCO2-07ER64494 and DE-SC0018409), the U.S. National Science Foundation (LTER program, DEB 1637653), and the Michigan State University AgBioResearch.

\section{ORCID}

Stephen K. Hamilton (D) http://orcid.org/0000-0002-4702-9017

\section{REFERENCES}

Abraha, M., Chen, J., Chu, H., Zenone, T., John, R., Su, Y.-J., ... Robertson, G. P. (2015). Evapotranspiration of annual and perennial biofuel crops in a variable climate. Global Change Biology. Bioenergy. https://doi.org/ 10.1111/gcbb.12239

Albertson, J. D., Katul, G. G., \& Wiberg, P. (2001). Relative importance of local and regional controls on coupled water, carbon, and energy fluxes. Advances in Water Resources, 24, 1101-1118.

Allen, R. G., Pereira, L. S., Raes, D., \& Smith, M. (1998). Crop evapotranspiration-Guidelines for computing crop water requirements (FAO irrigation and drainage paper 56, Food and Agricultural Organization, Rome).

Basso, B., \& Ritchie, J. T. (2012). Assessing the impact of management strategies on water use efficiency using soil-plant-atmosphere models. Vadose Zone Journal, 11(3). https://doi.org/10.2136/vzj2011.0173

Bosch, J. M., \& Hewlett, J. D. (1982). A review of catchment experiments to determine the effect of vegetation changes on water yield and evapotranspiration. Journal of Hydrology, 55(1/4), 3-23. 
Brown, A. E., Westem, A. W., McMahon, T. A., \& Zhang, L. (2013). Impact of forest cover changes on annual streamflow and flow duration curves. Journal of Hydrology, 483, 39-50.

Brown, A. E., Zhang, L., McMahon, T. A., Westem, A. W., \& Vertessy, R. A. (2005). A review of paired catchment studies for determining changes in water yield resulting from alterations in vegetation. Journal of Hydrology, 310, 28-61.

Donohue, R. J., Roderick, M. L., \& McVicar, T. R. (2007). On the importance of including vegetation dynamics in Budyko's hydrological model. Hydrology and Earth Systems Science, 11, 983-995. https://doi.org/ 10.5194/hess-11-983-2007

Donohue, R. J., Roderick, M. L., McVicar, T. R., \& Farquhar, G. D. (2013). Impact of $\mathrm{CO}_{2}$ fertilization on maximum foliage cover across the globe's warm, arid environments. Geophysical Research Letters, 40, 3031-3035. https://doi.org/10.1002/grl.50563

Gage, S. H., Doll, J. E., \& Safir, G. R. (2015). A crop stress index to predict climatic effects on row-crop agriculture in the U.S. North Central Region. In S. K. Hamilton, J. E. Doll, \& G. P. Robertson (Eds.), The ecology of agricultural landscapes: Long-term research on the path to sustainability (pp. 77-103). New York, New York, USA: Oxford University Press.

Gelfand, I., Sahajpal, R., Zhang, X., Izaurralde, R. C., Gross, K. L., \& Robertson, G. P. (2013). Sustainable bioenergy production from marginal lands in the US Midwest. Nature, 493, 514-517.

Hamilton, S. K., Hussain, M. Z., Bhardwaj, A. K., Basso, B., \& Robertson, G. P. (2015). Comparative water use by maize, perennial crops, restored prairie, and poplar trees in the US Midwest. Environmental Research Letters, 10, 065015. https://doi.org/10.1088/1748-9326/10/6/064015

Hanson, R. L. (1991). Evapotranspiration and droughts. In R. W. Paulson, E. B. Chase, R. S. Roberts, \& D. W. Moody (Eds.), Compilers, National Water Summary 1988-89: Hydrologic events and floods and droughts: U.S. Geological Survey Water-Supply Paper 2375 (pp. 99-104).

Hornbeck, J. W., Adams, M. B., Corbett, E. S., Verry, E. S., \& Lynch, J. A. (1993). Long-term impacts of forest treatments on water yield: A summary for northeastern USA. Journal of Hydrology, 150(2/4), 323-344.

Houghton, R. A., \& Hackler, J. L. (2000). Changes in terrestrial carbon storage in the United States. I: The roles of agriculture and forestry. Global Ecology and Biogeography, 9, 125-144.

Kunkle, K. (2015). Change in length of growing season by state, 18952014. Data from http://www3.epa.gov/climatechange/science/indicators/health-society/growing-season.html; downloaded 11 March 2016

Lark, T. J., Salmon, J. M., \& Gibbs, H. K. (2015). Cropland expansion outpaces agricultural and biofuel policies in the United States. Environmental Research Letters, 10, 044003 https://doi.org/10.1088/ 1748-9326/10/4/044003

Le, P. V. V., Kumar, P., \& Drewry, D. T. (2011). Implications for the hydrologic cycle under climate change due to the expansion of bioenergy crops in the Midwestern United States. Proceedings of the National Academy of Sciences of the USA, 108, 15085-15090.

Lim, K. J., Engel, B. A., Tang, Z., Choi, J., Kim, K., Muthukrishnan, S., \& Tripathy, D. (2005). Web GIS-based hydrograph analysis tool, WHAT. Journal of the American Water Resources Association, 41, 1407-1416.

McDonnell, J. J., \& Beven, K. (2014). Debates-The future of hydrological sciences: A (common) path forward? A call to action aimed at understanding velocities, celerities and residence time distributions of the headwater hydrograph. Water Resources Research, 50. https://doi. org/10.1002/2013WR015141

McVicar, T. R., Roderick, M. L., Donohue, R. J., Li, L. T., Van Niel, T. G., Thomas, A., ... Dinpashoh, Y. (2012). Global review and synthesis of trends in observed terrestrial near-surface wind speeds: Implications for evaporation. Journal of Hydrology, 416-417, 182-205. https://doi. org/10.1016/j.jhydrol.2011.10.024

McVicar, T. R., Roderick, M. L., Donohue, R. J., \& Van Niel, T. G. (2012). Less bluster ahead? Ecohydrological implications of global trends of terrestrial near-surface wind speeds. Ecohydrology, 5, 381-388. https://doi. org/10.1002/eco.1298
NCDC (National Climate Data Center). (2013). Summary of monthly normals 1981-2010. Gull Lake Biology Station, MI, USA. <http://www. ncdc.noaa.gov/cdo-web/search\%3e> Accessed January 17, 2013.

Parmesan, C., \& Hanley, M. E. (2015). Plants and climate change: Complexities and surprises. Annals of Botany, 116, 849-864.

Price, K. (2011). Effects of watershed topography, soils, land use, and climate on baseflow hydrology in humid regions: A review. Progress in Physical Geography, 35, 465-492.

Pugh, S. A. (2015). Forests of Michigan, 2014. Resource Update FS-35. Newtown Square, PA: U.S. Department of Agriculture, Forest Service, Northern Research Station. 4 p.

Ramankutty, N., Heller, E., \& Rhemtulla, J. (2010). Prevailing myths about agricultural abandonment and forest regrowth in the United States. Annals of the Association of American Geographers, 100, 502-512.

Rheaume, S. J. (1990). Geohydrology and water quality of Kalamazoo County, Michigan, 1986-88. U.S. Geological Survey Water-Resources Investigations Report 90-4028, 102 p.

Saad, D. A. (2008). Agriculture-related trends in groundwater quality of the glacial deposits aquifer, central Wisconsin. Journal of Environmental Quality, 37, S240-S248.

Simberloff, D. (2000). Global climate change and introduced species in United States forests. Science of the Total Environment, 262, 253-262.

Thoen, G. (1990). Soil survey of Barry County, Michigan. ( pp. 286). East Lansing, Michigan, Washington, DC: USDA Soil Conservation Service and Michigan Agricultural Experiment Station.

Trancoso, R., Larsen, J. R., McVicar, T. R., Phinn, S. R., \& McAlpine, C. A. (2017). $\mathrm{CO}_{2}$-vegetation feedbacks and other climate changes implicated in reducing base flow. Geophysical Research Letters, 44, 2310-2318. https://doi.org/10.1002/2017GL072759

Van Dijk, A. I. J. M., Peña-Arancibia, J. L., \& Bruijnzeel, L. A. (Sampurno) (2012). Land cover and water yield: Inference problems when comparing catchments with mixed land cover. Hydrology and Earth System Sciences, 16, 3461-3473. https://doi.org/10.5194/hess16-3461-2012

VanLoocke, A., Twine, T., Zeri, M., \& Bernacchi, C. J. (2012). A regional comparison of water use efficiency for miscanthus, switchgrass and maize. Agricultural and Forest Meteorology, 164, 82-95.

Wilcox, B. P., \& Huang, Y. (2010). Woody plant encroachment paradox: Rivers rebound as degraded grasslands convert to woodlands. Geophysical Research Letters, 37, L07402. https://doi.org/10.1029/ 2009GL041929

Wild, M. (2009). Global dimming and brightening: A review. Journal of Geophysical Research-Atmospheres, 114, D00D16. https://doi.org/ 10.1029/2008JD011470

Willett, K. M., Jones, P. D., Gillett, N. P., \& Thorne, P. W. (2008). Recent changes in surface humidity: Development of the HadCRUH dataset. Journal of Climate, 21, 5364-5383.

Williams, C. A., Reichstein, M., Buchmann, N., Baldocchi, D., Beer, C. Schwalm, C., ... Schaefer, K. (2012). Climate and vegetation controls on the surface water balance: Synthesis of evapotranspiration measured across a global network of flux towers. Water Resources Research, 48, W06523. https://doi.org/10.1029/2011WR011586

Yang, Y., Donohue, R. J., McVicar, T. R., Roderick, M. L., \& Beck, H. E. (2016). Long-term $\mathrm{CO}_{2}$ fertilization increases vegetation productivity and has little effect on hydrological partitioning in tropical rainforests. Journal of Geophysical Research - Biogeosciences, 121, 2125-2140. https://doi.org/10.1002/2016JG003475

Zhang, L., Dawes, W. R., \& Walker, G. R. (2001). Response of mean annual evapotranspiration to vegetation changes at catchment scale. Water Resources Research, 37, 701-708.

Zhang, Y., Peña-Arancibia, J. L., McVicar, T. R., Chiew, F. H. S., Vaze, J., Liu, C., ... Pan, M. (2016). Multi-decadal trends in global terrestrial evapotranspiration and its components. Scientific Reports, 6, 19124. https:// doi.org/10.1038/srep19124 
Zhuang, Q., Qin, Z., \& Chen, M. (2013). Biofuel, land and water: Switchgrass or Miscanthus? Environmental Research Letters, 8, 015020. https://doi. org/10.1088/1748-9326/8/1/015020

\section{SUPPORTING INFORMATION}

Additional Supporting Information may be found online in the supporting information tab for this article.
How to cite this article: Hamilton SK, Hussain MZ, Lowrie C, Basso B, Robertson GP. Evapotranspiration is resilient in the face of land cover and climate change in a humid temperate catchment. Hydrological Processes. 2018;1-9. https://doi.org/ 10.1002/hyp.11447 